\title{
TWO CONTRASTING NINETEENTH-CENTURY SURGEON DERMATOLOGISTS
}

\author{
by
}

\author{
D. GERAINT JAMES
}

\begin{abstract}
There is one period which you should regard your own, not only for the development of science and medicine in your own continent [of Australia], but also generally for the history of medicine and the history and philosophy of science as it is developing so rapidly today. It is a great century and it will come to be regarded as undoubtedly the greatest of centuries-greater than the Renaissance. It is the nineteenth century ... It is really the most tremendous age in the history of the world and we're only just beginning to realise it ... In many respects we are still living on its capital ... (Poynter, 1969).
\end{abstract}

We ARE certainly still living on the capital transmitted to the twentieth century by Erasmus Wilson and Jonathan Hutchinson, two colourful personalities who not only made distinguished contributions to dermatology but contributed richly to the London medical scene.

WILLIAM JAMES ERASMUS WILSON (1809-1884)

Erasmus Wilson was the son of an Aberdeen naval surgeon, who settled as a parish surgeon in Dartford and Greenhithe, Kent, but eventually opened a private asylum at Denham, Buckinghamshire.

Erasmus was born on 25 November 1809 at the house of his Norwegian maternal grandfather, Erasmus Bransdorph, in Marylebone High Street, London. In 1831, after his training at St. Bartholomew's Hospital, he became assistant to Jones Quain, Professor of Anatomy and Physiology at the University of London. When aged thirty-one years, he became lecturer in anatomy and physiology at the Middlesex Hospital and assistant editor of the Lancet under Thomas Wakley, whose son, Thomas Henry Wakley, he had coached (Plarr, 1930). He was consulting surgeon to the St. Pancras Infirmary, and on 20 February 1845 he was elected F.R.S.

The Editor of the Lancet guided him into dermatology, by advising him to become so identified with skins that when he entered a room the company would scratch themselves. Dermatology and skilful investments in the shares of gas and railway companies enabled him to leave a fortune of $£ 200,000$, most of which reverted to the Royal College of Surgeons after the death of Lady Wilson.

There can be no doubt of his generosity, for he restored Swanscombe Church, rebuilt the headmaster's house at Epsom College, founded a scholarship at the Royal College of Music, endowed a chair of pathology at Aberdeen University, and established a Chair of Dermatology at the Royal College of Surgeons. With the object of promoting the study of the Pathology together with the Anatomy and Physiology, human and comparative, of the Skin and its Appendages, Erasmus Wilson gave to the College the sum of $£ 5,000$ New Three Per Cent Consols, under a Deed of Trust, 


\section{Geraint James}

dated 8 July 1869, to found and endow a Professorship of Dermatology. The Council appointed Sir Erasmus Wilson to the Professorship, and during the period 1870-78 he delivered six lectures annually, and presented to the Museum a large collection of casts and models used in illustration of his lectures.

In 1879 certain alterations in the terms of the Trust were effected with the approval of the Founder, providing that the income derived from the Fund should be devoted to the promotion of original researches by lectures delivered at the College, the number of such lectures not to exceed three in any one year, and to be given by one or more persons to be called Erasmus Wilson Professors of Pathology.

In 1881 further alterations were thought desirable, and under a new Deed of Trust, dated 13 April 1882, it is now provided that the income of the Fund shall be appropriated in part towards the payment of the salary of a Pathological Curator of the Museum, and in part for the payment of lectures on the pathological contents of the Museum to be delivered by the Pathological Curator or some other person appointed for the purpose with the title of Erasmus Wilson Lecturer. Three lectures were delivered annually from 1882 to 1908 . In July 1908 it was decided to institute a series of lectures or demonstrations on advanced Surgical Pathology, illustrated by specimens in the Museum, and from 1909 the Erasmus Wilson Lectures have formed part of this series, six demonstrations being given annually, except in the years 1919 and 1920 when the demonstrations were suspended, and in 1925 when three lectures were given. The present honorarium of $£ 5$ for an Erasmus Wilson Demonstration would have saddened his generous nature, particularly when it is recalled that he paid $£ 10,000$ to transport Cleopatra's needle to London and paid $£ 30,000$ for a new wing and chapel to the Margate Seabathing Infirmary.

JONATHAN HUTCHINSON (1828-1913)

Jonathan Hutchinson was born nineteen years later than Wilson. Any comparison should bear in mind that he was of a younger generation, but nevertheless their paths were in many respects very similar.

He earned the title of the most famous general practitioner in the world because of his wide range of interests and appointments. He was Dermatologist at the Blackfriars Hospital for Diseases of the Skin, Ophthalmologist to the Royal London Ophthalmic Hospital, Venereologist to the Lock Hospital, Physician to the City of London Chest Hospital, and General Surgeon to the London and Metropolitan Hospitals. In addition to his Presidency of the Hunterian Society (1869) he was founder-secretary of the New Sydenham Society (1859-1907); President of the Royal College of Surgeons (1889); President of the Pathological Society of London (1879); President of the Ophthalmological Society of the United Kingdom (1883); President of the Neurological Society (1887); President of the Medical Society of London (1892); President of the Royal Medical and Chirurgical Society (1894-96); and President of the 1896 International Dermatology Congress.

BACKGROUND, EDUCATION AND QUALIFICATIONS

Erasmus Wilson, born on 25 November 1809, was a Londoner of Scottish and Norwegian protestant ancestry. He was a doctor's son. He was educated at Dartford 


\section{Two Contrasting Nineteenth-Century Surgeon Dermatologists}

Grammar School and afterwards at Swanscombe, Kent. He attended John Abernethy's anatomy lectures at St. Bartholomew's Hospital. Jonathan Hutchinson was born on 23 July 1828, the second son of Jonathan Hutchinson and Elizabeth Massey, both members of the Society of Friends at Selby, Yorkshire. After early education at Selby and the York School of Medicine, he also went to St. Bartholomew's where he came under the influence of his teacher, Sir James Paget.

They both became Licentiates of the Society of Apothecaries and Members, and later Fellows, of the Royal College of Surgeons at an early age (Table 1). Likewise, they were both elected to the Fellowship of the Royal Society, Wilson when aged thirty-six years and Hutchinson when he was fifty-four years old.

TABLE 1

A Comparison of the Professional and Social Milestones in the lives of Erasmus Wilson AND JONATHAN HUTCHINSON.

\begin{tabular}{|l|l|l|}
\hline & ERASMUS WILSON & JonAtHAN Hutcrinson \\
\hline Born & $25.1 .1809-$ London & 3.7 .1828 - Yorkshire \\
Barts & $1825:$ Aged 16 & 1850 Aged 22 \\
Influence & John Abernethy & James Paget \\
L.S.A. & Aged 21 (1830) & Aged 22 (1850) \\
M.R.C.S. & Aged 22 (1831) & Aged 22 (1850) \\
Editor & Lancet (Assistant)-1840 & British Medical Journal-1869 \\
Married & 1841 - Miss Doherty & 1856 - Miss Jane \\
F.R.C.S. & 1843 & 1862 \\
F.R.S. & 1845 & 1862 \\
P.R.C.S. & 1881 & 1889 \\
Knighthood & 1881 & 1908 \\
\hline
\end{tabular}

Their association with the College of Surgeons was capped by election to the Presidency, Wilson in 1881 and Hutchinson in 1889. Erasmus Wilson received his knighthood during his Presidency, but Hutchinson was to wait until he was an octogenarian for the King's pleasure to be announced in the Honours List of June 1908.

\section{DERMATOLOGY}

Thomas Wakley of the Lancet guided Erasmus Wilson to dermatology, to which he devoted himself from about 1840 onwards. He wrote voluminously on the subject (Table 2), and in 1870 presented to the College of Surgeons his extensive and valuable collection of drawings and models illustrating diseases of the skin. The College marked its appreciation of these benefactions by presenting him with its Honorary Medal, which had only been bestowed thirteen times since it was instituted in $\mathbf{1 8 0 2}$. 


\section{Geraint James}

He popularized the use of the ordinary bath as well as the Turkish bath in England. From the proceeds of his large dermatological practice, he gave $£ 5,000$ to found a chair of dermatology at the Royal College of Surgeons; and it was fitting that he was the first Professor (1870-1878). He was also founder-editor of the Journal of Cutaneous Medicine.

TABLE 2

ERASMUS Wilson's WrITINGS

$\begin{array}{ll}1837 & \text { The Vessels of the Human Body (with Quain) } \\ 1838 & \text { Practical and Surgical Anatomy } \\ 1840 & \text { The Anatomist's Vade Mecum } \\ 1842 & \text { Diseases of the Skin } \\ 1845 & \text { History of The Middlesex Hospital } \\ 1848-55 & \text { Atlas of Diseases of the Skin } \\ 1861 & \text { The Eastern or Turkish Bath } \\ 1867-70 & \text { Founder-Editor Journal of Cutaneous Medicine and Diseases } \\ \text { of the Skin }\end{array}$

Jonathan Hutchinson has left to posterity his own contributions to dermatology in his Archives of Surgery and elsewhere, a series of eponyms which include Mortimer's Malady, Penmann's Disease, Mabey's Malady, and Mrs. Branford's Legs.

Indelibly printed in the world literature are Hutchinson's triad of interstitial keratitis, congenital syphilitic teeth and labryrinthine disease; Hutchinson's mask-like facies in tabes dorsalis; Hutchinson's chronic skin plaques in sarcoidosis; and Hutchinson's unequal pupils in meningeal haemorrhage.

Hutchinson was on the staff of the Blackfriars Skin Hospital; and became President of the International Congress of Dermatology held in 1896 in London.

His clinical collection of illustrations of skin diseases and other material was so vast that it was refused, for lack of space, by the Royal Colleges of Surgeons and of Physicians, but was acquired after his death by the Johns Hopkins Medical School through the agency of Sir William Osler and the financial generosity of Mr. W. A. Marburg (McKusick, 1952).

\section{MEDICAL SOCIETY OF LONDON}

Both men were active in the affairs of London medical societies, and the Medical Society of London was fortunate to enjoy their close participation. Erasmus Wilson was its Orator (1876) and President (1878) just before becoming P.R.C.S. (1881); likewise Jonathan Hutchinson, who was Orator (1889) in the same year as he was P.R.C.S. (1889), followed by Presidency of the Medical Society of London (1892). Jonathan Hutchinson was also invited to deliver the Society's Lettsomian Lecture in 1886 on 'On some Moot Points in the Natural History of Syphilis'.

The Medical Society of London might have inherited a large share of Erasmus Wilson's estate of $£ 200,000$, for it already possessed a three-quarter length oil painting of Wilson in the robes of a lecturer at the Royal College of Surgeons, painted by Stephen Pearce. It now hangs in the Council Chamber of the Society's Rooms in Chandos Street (fig. 1). He was justifiably proud of this painting for it had been exhibited in the Royal Academy (1840), and it was natural that he should expect it to have a place of honour in the Society's Hall. It is said that he was horrified and 

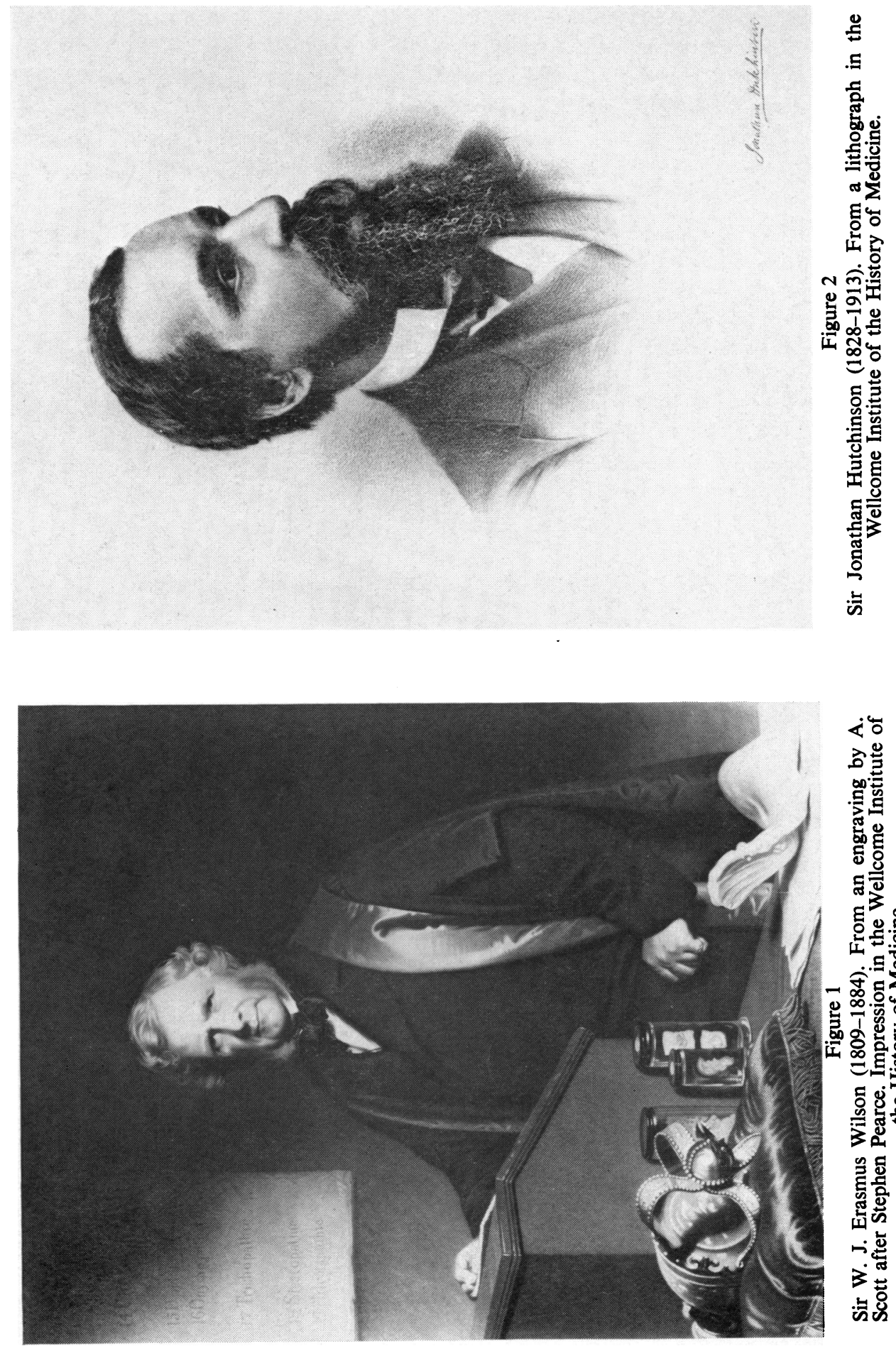

<

อัด

然

管。

을

50

E 응. 证

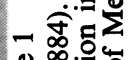

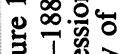
品 工象 고

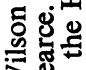
30 号

हีํํㄹ 焉总 承 3 㖪 


\section{Two Contrasting Nineteenth-Century Surgeon Dermatologists}

incensed to find, in the course of a visit, that the painting had been relegated to a basement, and for this insensitive act he cut the Medical Society of London out of his will. The Society's loss was to the Royal College of Surgeons' gain, so it is hoped that the College will help to clean this splendid Academy portrait and allow the faded inscriptions behind his right shoulder to be deciphered, and the pathology pots in front of his left hand to be recognized. It is a long-established rumour that one of the pots carries Napoleon's stomach, so the present Curator of this collection receives many requests for sample specimens; in fact, there is no basis to this apocryphal story.

\section{MEDICAL EDITORS}

Attention has already been drawn to their voluminous writings and carefully annotated clinical collections. What is less well known is that this may have come about because each had enjoyed a writer's baptism with one or other of Britain's two weekly medical journals. Erasmus Wilson was assistant editor to Thomas Wakley of the Lancet in 1840, whereas Jonathan Hutchinson was associated with the British Medical Journal. We should attribute to 1969 not only the centenary of the first recognition of sarcoidosis by Jonathan Hutchinson, but also the centenary of his editorship of the British Medical Journal. In 1869 he succeeded Ernest Hart and was soon launched on a variety of topics including the Constitution of the College of Surgeons, Public Health, Medical Reform, Hospital Architecture, Listerism, Antivivisection, Medical examinations, Syphilography, Malthusianism and Over-population, Pediculosis, Davey's discovery of Faraday, and Ars Longa (Hutchinson, 1946).

\section{SOCLAL}

Erasmus Wilson was an extrovert mesomorph who enjoyed foreign travel and total participation in London life. He was. President of the Biblical Archaeological Society, served as Master of the Clothworkers' Company, and he was a prominent freemason. In 1841, he married Miss Doherty; she survived him but there were no children. Jonathan Hutchinson was a thoughtful ectomorph, who married Miss Jean Pynsent West in 1856 . His wife predeceased him in 1886 . Their family comprised six sons and four daughters. One son, Jonathan, followed his father as surgeon to the London Hospital; another, Proctor, a laryngologist, died early; Roger Jackson was in practice at Haslemere; and H. Hutchinson became an architect.

Both were good swimmers, but probably in different ways. Wilson won the Silver Medal of the Royal Humane Society for saving the life of Olivia Green, who attempted to commit suicide by jumping into the Regent's Park Canal on 22 April 1857. Hutchinson swam in a cold-water pool in the grounds of his Haslemere home until nearly the end of his life.

\section{LEGACY}

Wilson was a Church of England Freemason and Hutchinson a dedicated Quaker. The former died at Westgate aged seventy-four years and the latter at his Haslemere home aged eighty-four years (Table 3 ). The legacy which each has contributed is priceless for, as Poynter (1969) has indicated, we of the twentieth century are still living on their capital. 


\section{Geraint James}

TABLE 3

A Comparison of the Interrests of WiLson and Hutchinson

\begin{tabular}{|c|c|c|}
\hline & Erasmus WILSON & JONATHAN HUTCHINSON \\
\hline \multirow[t]{3}{*}{ Med. Soc. Lond. } & President (1878) & President (1892) \\
\hline & Orator (1876) & Orator (1889) \\
\hline & & Lettsomian Lecturer (1886) \\
\hline Dermatologist & $\begin{array}{l}\text { Professor of Dermatology } \\
\text { R.C.S. (1869-1878) } \\
\text { 1867: Founder-Editor } \\
\text { J. Cutan. Med. }\end{array}$ & $\begin{array}{l}\text { Blackfriars Skin Hospital } \\
\text { President, Int. Cong. } \\
\text { Dermat. (1896) }\end{array}$ \\
\hline Clinical Museum & $\begin{array}{l}\text { On Pathology of the Skin } \\
\text {-inherited by R.C.S. }\end{array}$ & $\begin{array}{l}\text { Collection of Illustrations } \\
\text {-inherited by Johns } \\
\text { Hopkins Hospital, } \\
\text { Baltimore }\end{array}$ \\
\hline Died & 1884-Ared 74 (Westeate) & 1913-Aged 84 (Haslemere) \\
\hline Philosophy & Freemason & Quaker \\
\hline Children & None & 6 sons; 4 daughters \\
\hline
\end{tabular}

\section{REFERENCES}

Hutchinson, H., Jonathan Hutchinson, London, Heinemann, 1946.

James, D. Grraint, Brit. med. J., 1969, ii, 109.

McKusicx, V. A., Amer. J. Syph. Gon. and V.D., 1952, 36, 101.

PLARR, V. G., Lives of the Fellows of the Royal.College of Surgeons of England, London, Royal College of Surgeons, 1930, 2 vols.

Poynter, F. N. L., Bull. Post-Grad. Comm. Med., Sydney, 1969, 24, no. 11. 